\title{
Ynari e o poder das palavras
}

Marinês Andrea Kunz ${ }^{1}$

Resumo: Este artigo parte da Lei 10.639/03, que exige que a escola aborde a história de África e dos africanos e a luta dos negros no Brasil, a cultura negra e o negro na formação da sociedade nacional, resgatando as suas contribuições nas áreas social, econômica, política e histórica, para chegar à análise de "Ynari, menina das cinco tranças" do escritor angolano Ondjaki.

Palavras-chave: Lei 10.639/03, História, Literatura, África, Ondjaki

\begin{abstract}
This article analyzes the Law 10.639/03, which requires the school to study the history of Africa and the fight of black men in Brazil; the black culture and the black men in the formation of the national society, rescuing their social, economic, political and historical contributions. This analysis guides the study of the book of the Angolan writer Ondjaki: “ Ynari, menina das cinco tranças “
\end{abstract}

Keywords: Law 10.639/03, History, Literature, Africa, Ondjaki

Introdução

Em 2003, foi promulgada a Lei 10.639/03, que prevê o estudo da história e da cultura africanas nas escolas publicas e privadas, tanto no Ensino Fundamental como no Médio, com o intuito de se reconhecer e valorizar o papel dessa cultura na formação do Brasil. A lei prevê que a escola aborde a história de África e dos africanos e a luta dos negros no Brasil, a cultura negra e o negro na formação da sociedade nacional, resgatando as suas contribuições nas áreas social, econômica, política e histórica.

O objetivo é justamente dar visibilidade a esse grupo étnico, que, ao lado do europeu e do indígena, construiu este país, embora sempre lhe tenha sido negligenciado tal reconhecimento. Buscou-se sempre o silenciamento e o apagamento dessa cultura, negando-lhe os méritos de sua participação sócio-histórica-cultural na formação da nação brasileira. Nesse sentido, a citada lei permite a revisão dos focos educativos eurocêntricos, conferindo, oficialmente e pela primeira vez, o devido lugar ao negro na história da nação brasileira. Possibilita, assim, o rompimento de preconceitos arraigados, a partir da revisão histórica e da visibilidade aos afrodescendentes, junto às novas gerações de brasileiros, que terão a oportunidade de conhecer mais sobre o continente que gestou grande parte de nossa rica bagagem cultural. 
Com isso, certamente, revisar-se-á a própria identidade nacional. Como afirma, pois, Antônio Cândido, no prefácio à obra Raízes do Brasil, de Sérgio Buarque de Holanda, “[... ] registrar o passado não é falar de si; é falar dos que participaram de uma certa ordem de interesses e de visão do mundo, no momento particular do tempo que se deseja evocar" (CÂNDIDO, in: HOLANDA, 2010, p. 9). Isso se faz urgente, já que, como destaca Florestan Fernandes (1989, p. 13), a falsa ideia da "[...] democracia racial não só se arraigou. Ela se tornou mores, a pedra de toque da 'contribuição brasileira' ao processo civilizatório da Humanidade", mascarando até hoje as reais relações de exclusão, de apagamento e de silenciamento dessa grande parcela da sociedade brasileira.

Conhecer as raízes do continente africano, com sua variedade social e cultural, antes e depois da escravidão, faz parte dessa revisão da história nacional e da formação da sociedade brasileira. Tal projeto prevê o conhecimento de uma face de nossa história muitas vezes negada e relegada a segundo ou terceiro plano, tornada invisível pelos discursos oficiais.

Não raro, faz-se necessária uma lei para modificar à força formas cristalizadas de ver o mundo, que fazem com que a sociedade nem perceba que pode ser diferente ou que há mais culturas a permear a cultura brasileira, que não a portuguesa - ou a europeia. A partir da reformulação do olhar, pode-se ver o negro para além da música e da dança, avaliando, com isso, mais aprofundadamente sua contribuição, em todos os setores, para a construção da história e do acervo cultural brasileiro - a construção da identidade nacional.

Para empreender esse projeto, são necessárias produções bibliográficas, entre outros materiais, como mapas, por exemplo, tanto na área da História e da Geografia quanto da Literatura. As editoras, então, passaram a suprir tal demanda, de modo que surgiram inúmeras publicações sobre a temática negra. Obras que abordam a geografia do continente africano, que é, muitas vezes, entendido equivocadamente como um único país e, portanto, com características únicas. Amplia-se, assim, a noção de África, paralelamente à retomada dos processos históricos de compra e venda de negros escravizados, que revela a origem desses que foram trazidos não somente para o Brasil, mas para os demais países das Américas $^{2}$. Além disso, nessas obras, percebe-se outro aspecto importante que é o destaque conferido às diferenças étnico-culturais desses diferentes povos trazidos de África - "stolen from Africa, brought to America/ Fighting on arrival, fighting for survival”" (Bob Marley).

Outra área a ser suprida com material de leitura é justamente a literária, que, por muito tempo, no Brasil, tornou invisível o negro, especialmente na literatura infanto-juvenil, quando não o representava como pobre ou mesmo ladrão. Essa representação negativa ou inexistente marcou gerações, que não tinham na produção cultural um espelho que lhes refletisse uma identidade positiva. Uma das primeiras obras a representarem positivamente a negritude é Menina bonita do laço de fita, da autoria de Ana Maria Machado (Editora Ática). Este livro foi amplamente lido no espaço escolar, o que revela o público ávido ${ }^{3}$ por textos sobre a temática e, em 2010, estava na $8^{\mathrm{a}}$ edição.

Nesse sentido, hoje, muitas obras literárias ${ }^{4}$ apresentam o negro como personagem

2 As obras África e Brasil Africano, de Marina de Mello e Souza, e Uma história da cultura afro-brasileira, de Walter Fraga e Wlamyra R. de Albuquerque, abordam essas temáticas.

3 No projeto de Extensão Comunitária Ler..., desenvolvido em parceria pela Universidade Feevale, a FACCAT - Faculdades de Taquara e o Grupo Editorial Sinos, por exemplo, foi criado, em 2006, um fascículo com textos literários abordando esta temática. Inicialmente, temia-se sua recepção negativa, o que, contudo, não ocorreu. Ao contrário, este foi um dos fascículos mais bem recebidos e aprovados pelos professores e alunos participantes do projeto, em mais de 40 municípios da região.

4 Como exemplo, pode-se citar os autores André Neves, Rogério Andrade Barbosa, Décio Gioielli, Ruth Rocha e Simone Saueressig, entre tantos, que escrevem sobre o negro ou sobre a cultura africana. Muito antes da legislação, Simone Saueressig já publicava textos sobre a cultura afrobrasileira, como O Palácio de Ifê (1989), em que aborda corajosamente as figuras da mitologia africana. Mais recentemente, publicou A estrela de Iemanjá (2009). 
ou retomam mitos e lendas africanas, dando a conhecer a cultura dos povos negros de África. A literatura projeta e sedimenta o imaginário cultural, fazendo referência, por exemplo, a mitos e tradições folclóricas, culturalmente engendradas, o que "confirma o sentido de orientação transhistórica e mítico-simbólica que a caracteriza” (REIS, 2003, p. 93). Diante disso, a produção literária sobre o universo sócio-histórico-cultural da África negra é, indubitavelmente, crucial nesse processo deflagrado pela referida Lei.

Aspecto fundamental também são as ilustrações dessas obras, principalmente as destinadas ao público infantil e juvenil, as quais foram revistas, construindo sentidos eufóricos em relação à identidade negra e ao ambiente geográfico-cultural africano, como é o caso, por exemplo, das obras As tranças de Bintou, da autoria de Sylviane Anna Diouf, ilustrada por Shane W. Evans, e Flora, de Bartolomeu Campos de Queirós, ilustrada por Ellen Pestili.

Contudo, ao lado de obras de autores brasileiros sobre a cultura africana e o negro, há que se chamar a atenção para autores africanos, especialmente os de língua portuguesa, publicados no Brasil. Entre eles, podemos citar Roberto Chichorro, Mia Couto, José Eduardo Agualusa, Zetho Cunha Gonçalves e Ondjaki.

Obras de autores africanos fortalecem e intensificam o contato com o universo cultural africano, marcado pela oralidade, por mitos e ritos, que refletem a vida do homem, o que consiste em uma marca da universalidade. A partir dessa perspectiva, objetiva-se analisar, aqui, a obra Ynari, a menina das cinco tranças, do escritor angolano Ondjaki, ilustrada por Joana Lira.

O jovem escritor angolano Ondjaki já possui significativa trajetória literária. É poeta, contista e romancista, tendo recebido prêmios importantes, como o da Fundação Nacional do Livro Infantil e Juvenil, em 2010, pelo livro AvóDezanove e o segredo soviético. Escreveu, entre outras obras, Actu sanguíneu (2000), Há aprendisajens com o xão (2002), Momentos de aqui (2001), E se amanhã o medo (2004) Quantas madrugadas tem a noite (2004) e Bom dia camaradas (2003). Foi traduzido para vários idiomas, como francês, espanhol e alemão.

Ynari, suas tranças e as palavras

"Nós, os filhos desta terra, sabemos que os espíritos dos mortos estão por toda a parte, e que tentam comunicar conosco através do rumor das ramagens, e do sopro do vento, do canto das aves e da chuva que cai. [...] Nós sabemos falar vento, falar chuva, sabemos conversar com o capim e o capim diz-nos para onde foram as gazelas ou onde se escondem nossos inimigos."

José Eduardo Agualusa

O início da narrativa inscreve-se na tradição dos contos maravilhosos ao adotar a fórmula "Era uma vez...", convidando o receptor a um contrato de leitura que aceita a natureza fabulosa, mágica e simbólica da matéria do texto, plasmada na cultura oral e coletiva ao longo da história da humanidade. Como afirma Benjamin,

[...] o narrador figura entre os mestres e os sábios. Ele sabe dar conselhos: não para alguns casos, como o provérbio, mas para muitos casos, como o sábio. Pois pode recorrer ao acervo de toda uma vida (uma vida que não inclui apenas a própria experiência, mas em grande parte a experiência alheia. $\mathrm{O}$ narrador assimila à sua substância mais íntima aquilo que sabe por ouvir dizer.). (BENJAMIN, 1994, p. 221). 
Esta narrativa, que aborda o poder mágico e simbólico da palavra, está, assim, enredada pela cultura coletiva.

A protagonista desta história é Ynari, uma menina com cinco lindas tranças, que, passeando perto do rio, encontra um homem muito pequeno. Em contato com ele, Ynari passa a refletir sobre o sentido e o poder das palavras, o que a leva a um processo de autoconhecimento.

Este homem muito pequenino problematiza a noção de tamanho ao falar das pessoas de sua aldeia, ensinando Ynari que a noção de pequeno - e de tudo no mundo - é relativa e pode variar de acordo com o ponto de vista. Inicia-se, então, entre eles, a reflexão sobre o sentido das palavras. Sobre a palavra coração, a menina destaca que este pode ou não ser pequeno: pequeno, porque bate dentro do peito, mas grande, recuperando o sentido metafórico do termo, porque muitas coisas cabem dentro dele, como a família e os amigos.

O homem pequenino conduz a menina em uma descoberta acerca dos sentidos da palavra, fundada na relatividade e na subjetividade, ou seja, o sentido está ligado ao ponto de vista do enunciador, cuja percepção atua como elemento modificador do signo. Essa subjetividade, por sua vez, é fruto tanto da percepção individual como do universo cultural que a engendra, podendo ser, portanto, diversa em cada grupo. De acordo com Laraia (2009, p. 45), "o homem é o resultado do meio cultural em que foi socializado. Ele é o herdeiro de um longo processo cumulativo, que reflete o conhecimento e a experiencia adquiridas pelas numerosas gerações que o antecederam.",

O homem pequenino pergunta sobre suas tranças, dando início ao autoconhecimento da protagonista e o fulcro de sua ação na narrativa. Ynari explica que nasceu com elas e que, segundo sua avó - personagem marcada pela sabedoria de quem já viveu muito -, um dia ela saberá porquê. Este diálogo anuncia a continuidade das ações e, portanto, a trajetória de Ynari rumo ao conhecimento de si mesma, por meio da descoberta do poder e da importância das palavras, bem como o objetivo de ter nascido de tranças. Nesse percurso, o homem pequenino passa a não parecer-lhe mais tão pequeno, o que indicia a mudança interior da menina, refletida em sua forma de ver o mundo.

Em sonho, é antecipada a jornada de autoconhecimento de Ynari, a qual também se distingue das outras crianças de sua idade, o que fica evidente quanto afirma que "era difícil explicar às crianças de sua idade como gostava de palavras, e o que as palavras podiam fazer entre duas pessoas" (ONDJAKI, 2010, p. 13) ${ }^{5}$, referindo-se aqui ao papel dos signos lingüísticos nas inter-relações humanas. A interação social é o espaço em que a palavra ganha vida: "a palavra penetra literalmente em todas as relações entre indivíduos [...]. As palavras são tecidas a partir de uma multidão de fios ideológicos e servem de trama a todas as relações sociais em todos os domínios" (BAKHTIN, 2006, p. 42).

Ynari aponta, ainda, para o poder das palavras ainda desconhecidas, mas que vivem no coração das pessoas, embora nunca tenham estado em sua boca. Essas palavras remetem justamente ao universo sócio-histórico-cultural em que se insere o sujeito, como um acervo atávico prestes a brotar em sua boca, já que habita-lhe o coração. Isso decorre do fato de que a forma de perceber as coisas do mundo se dá pela linguagem, pois somente por meio das formas simbólicas o real pode converter-se em objeto de captação intelectual e, assim, tornar-se visível ao sujeito (CASSIRER, p. 22). E a linguagem, por sua vez, é permeada pelo histórico-cultural, repleto de formas simbólicas.

Após essas observações de Ynari, passam a ocorrer situações que a levam ao aprendizado na prática, operando nela as mudanças sutilmente já anunciadas. Quando

5 Todas as citações da obra em análise serão referidas, deste ponto em diante, apenas com o número de página. 
surgem homens armados lutando entre si, ambos se escondem e observam toda a ação. Após a luta, enquanto os homens dormem, o homem pequenino "mexia-se de um modo estranho e dizia, baixinho, umas tantas palavras. De repente, as armas dos homens que estavam a dormir transformaram-se em armas de barro" (p. 16). A menina, assistindo a tudo, conclui que, além de pequeno, o homem é mágico. Pelo poder da palavra, ele transformou as armas de metal em armas de barro, modificando a realidade.

A ilustração reforça a narrativa verbal, na medida em que toda a paisagem é representada em tons de branco, ao passo que os homens em luta estão em vermelho, contraste que investe de sentidos negativos a situação de guerra. Como que de fora desse espaço em branco, sob o azul do céu, Ynari observa a situação e o homem pequenino transforma as armas, o que leva a concluir que o conflito não lhes pertence.

O homem pequeno leva-a a sua aldeia, onde não há soba, ou seja, não há necessidade de um líder, já que este papel é desempenhado pelas pessoas mais velhas e detentoras de sabedoria. É com esse sentido que the apresenta duas pessoas de idade avançada dotadas de sabedoria: um velho muito velho com longa barba branca quase até o chão, que mora em uma árvore "muito antiga" e que inventa palavras; e uma "velha muito velha que destrói as palavras" (p. 19). A figura do velho como fonte de saber é uma constante na narrativa, elemento cultural que revela a transmissão dos ensinamentos aos mais jovens por parte dos mais velhos, mais experimentados, detentores da memória do grupo.

Enquanto é preparada uma festa, o homem pequeno explica à menina que não só ele é mágico, mas que todas as pessoas o são e que "cada um tem que descobrir a sua magia" (p. 19). Ou seja, pelo poder do verbo, cada indivíduo atua sobre a realidade e por ela é permeado.

Durante a festa, Ynari assiste a um ritual. No centro do grupo, há uma cabaça em que o velho e a velha colocam muitas ervas enquanto dizem palavras incompreensíveis a Ynari. Algumas pessoas dizem palavras ao pé do ouvido da velha muito velha, a qual decide destruir algumas delas: "são palavras que já não servem para nada, e têm que desaparecer..." (p. 21). Já o velho muito velho coloca outras ervas na cabaça. Algumas pessoas bebem um pouco do líquido e aproximam-se dele, que lhes diz uma palavra ao pé do ouvido. Elas, então, partem da aldeia, para voltar somente no próximo cacimbo. Opera-se, nesse ritual, um processo de renovação por meio do poder transformador da linguagem e, consequentemente, da vida: palavras inúteis são destruídas e palavras novas e úteis são criadas.

Ao ser chamada ao centro, Ynari pergunta se saberá sua magia, ao que a velha muito velha responde:

Cada pessoa sua magia; cada árvore sua raiz. O peixe só sabe nadar na água. O humbihumbi preso, nas gaiolas, morre. Coisa de metal que sai metal e fumo, destruímos. Coisa de metal que vira semente e mata, destruímos. De noite, olhar e respeitar as estrelas. De dia, olhar e imitar os animais. Primeiro somos crianças, depois somos caçadores, depois temos crianças, depois ficamos a olhar as crianças. O cágado, sempre lento, é quem chega primeiro. Mais sabedoria tem a palanca negra gigante que só olha os homens de longe. Falei. (p. 22- 23).

Esse discurso é complementado pela fala do velho muito velho que cria palavras, como em um processo especular:

Cada rio suas águas; cada céu suas nuvens. Peixe dentro da água brinca, fora da água sofre. O humbi-humbi não conhece gaiola, só respeita nuvem. Coisa de metal que sai 
fumo, vira barro. Coisa de metal como semente, vira imbondeiro. De noite, as estrelas olhar e uma só escolher. De dia, os animais caçar, seja, o alimento. Primeiro somos criança e coração bate. Depois somos caçados por nosso coração. Depois descobrimos criança no coração. Depois a criança nos ensina outros caminhos do coração. O cágado também sabe perder. A palanca negra também sabe fugir. Falei. (p. 23).

As palavras dos dois velhos são complementares e estão calcadas na observação da natureza e na sabedoria atávica. Não no conhecimento científico, mas aquele que brota das vivências e do conhecimento passado de geração a geração, por meio da linguagem oral, destacada, nessa narrativa, pela expressão "Falei", empregada por ambos os velhos detentores da sabedoria como fórmula de poder.

Pode-se refletir sobre isso, a partir de trecho de Wilhelm Von Humboldt, citado por Cassirer:

O homem vive com seus objetos fundamental e até exclusivamente, tal como a linguagem lhos apresenta, pois nele o sentir e o atuar dependem de suas representações. Pelo mesmo ato, mediante o qual o homem extrai de si a trama da linguagem, também vai se entretecendo nela e cada linguagem traça um círculo mágico ao redor do povo a que pertence, círculo do qual não existe escapatória possível, a não ser que se pule para outro. (HUMBOLDT, apud CASSIRER, 2006, p. 23).

A palavra e o ato estão, assim, imbricados, de modo que falar é também fazer. Daí o poder mágico da palavra, que incide sobre a realidade, sendo que a própria experiência primária está impregnada deste configurar de mitos e como que saturada de sua atmosfera (CASSIRER, 2010).

Essa relação entre o mito e a linguagem está representada também na ilustração (Anexo), em que Ynari, em primeiro plano, segura a cabaça diante da boca, com suas mãos, nas quais estão sobrepostas as imagens do velho e da velha, um de frente para o outro. As tranças da menina estão repletas de elementos da natureza e com corações, enquanto seus ombros e braços estão cobertos por pessoas, sendo que a maioria de boca aberta, como que a falar. O conhecimento é, assim, representado como fruto das relações humanas permeadas pela linguagem e fundado na experiência primária, transmitida oralmente ao longo das gerações. Linguagem, mito, arte e ciência condicionam-se mutuamente.

Cassirer explica que

O homem só vive com as coisas na medida em que vive nestas configurações, ele abre a realidade para si mesmo e por sua vez se abre para ela, quando introduz a si próprio e o mundo neste médium dútil, no qual os dois mundos não só se tocam, mas também se interpenetram. (CASSIRER, p. 2010, p. 24)

Enredada pelo poder mágico da palavra, Ynari parte com a certeza de que ela mesma deve descobrir sua magia, levando consigo a palavra "permuta" e a fórmula, que está em seu coração, ambas concedidas pelos velhos muito velhos. A mudança deve, portanto, operar-se em seu íntimo, por meio da autopercepção. À noite sonha com um velho muito velho que lhe explica o significado da palavra permuta.

No encontro seguinte com o homem pequenino, Ynari reflete sobre o sentido da palavra guerra, e o amigo explica-lhe que esta palavra não serve para nada, da mesma forma que a palavra explosão só deveria ser empregada no sentido de "explosão de alegria" e "explosão de cores". Permeada pela nova forma de ver o mundo em seu íntimo, Ynari conclui que "quando se sabe ver as coisas simples da vida descobre-se que o mundo é muito, muito bonito" (p. 28). O ponto de vista, modificado, pela linguagem, revela-lhe um novo mundo. 
Ynari descobre, então, a sua magia e pede que o homem pequenino a acompanhe a cinco aldeias, pois tinha aprendido com ele que "um lugar fica muito perto se quisermos que esse lugar esteja perto de nós" (p. 29). Em cada uma das aldeias, ela opera modificações em seus moradores, por meio da troca de palavras inúteis por outras úteis.

A primeira aldeia estava em guerra com outra, porque não podiam ouvir o som dos pássaros e das cachoeiras, como os inimigos ouvem. A menina lhe propõe ensiná-los a usar a palavra "ouvir", sendo que em troca deveriam cessar a guerra. Inicia um ritual, em que todos os membros deveriam trazer um pouco de água do rio em suas mãos e colocála em uma cabaça. A água, aqui, pode ser entendida como vida e energia, necessárias para a modificação em processo. Ynari diz algumas palavras e, logo, ouve-se a palavra "permuta". Ela corta uma de suas tranças e coloca-a na cabaça. Durante a noite, ocorre a mudança no povo da aldeia e, no dia seguinte, da cabaça saía ainda fumaça e todos ouviam os passarinhos. A permuta ocorreu.

$\mathrm{Na}$ segunda, as pessoas não conseguiam falar e se comunicavam por gestos, de modo que estavam em guerra com outra aldeia que sabia falar. Repete-se o ritual e ela corta a quarta trança, e a aldeia acorda aos gritos, pois todos tinham aprendido a falar. $\mathrm{Na}$ terceira aldeia, as pessoas não sabiam ver e, por isso, guerreavam com outra. Operada a permuta por meio do ritual e do corte da terceira trança, todos aprenderam a ver. $\mathrm{Na}$ seguinte, não sabiam cheirar e na última, sentir o sabor dos alimentos.

Todas as mudanças nas cinco aldeias ocorrem durante a noite, quando são realizados os rituais religiosos africanos. Segundo Chevalier, a noite

simboliza o tempo das gestações, das germinações, das conspirações, que vão desabrochar em pleno dia como manifestação da vida. [...] a noite apresenta um duplo aspecto, o das trevas onde fermenta o vir a ser, e o da preparação do dia, de onde brotará a luz da vida. (1998, p. 640).

Assim, pela manhã, os moradores das aldeias acordam modificados pelo poder mágico das palavras e pelo elemento ritualístico do corte das tranças de Ynari. Estas simbolizam a ligação deste mundo com o mundo dos mortos, representando "um enlace íntimo de relações, correntes de influência misturadas, a interdependência dos seres" (CHEVALIER, 1998, p. 895). A ligação desses dois mundos representa a espiritualidade dessa cultura, continuada de geração em geração: presente no velho de barbas, na velha de tranças e renovada na menina Ynari, em processo de autodescobrimento. É esta menina que auxilia os membros das aldeias, liderados sempre por um velho, a ouvir, falar, ver, sentir os cheiros e os sabores - habilidades básicas para o ser humano -, indicando a necessidade de renovação do conhecimento atávico na figura da criança, como um eterno processo de continuidade que garante a manutenção do conhecimento.

Em todas as aldeias, Ynari pede que deixem de usar a palavra guerra, uma vez que seu significado é semelhante ao de "desaparecer" e com as palavras "deixar de viver". O texto aponta para o resultado do não emprego da palavra "guerra", que é justamente a sua não mais existência.

Esse pedido não é fortuito se relacionado à história recente de Angola, destroçada, primeiramente, pelas guerras de independência contra Portugal e, depois, pelas lutas internas entre os grupos divergentes. O desejo coletivo expresso nesta obra é, pois, o fim da guerra e a renovação da vida, uma vida de paz, em que todos possam se expressar livremente (falar) e suprir as necessidades básicas (ver, ouvir, sentir cheiros e sabores), o 


\section{Conexão Letras}

que é conseguido por intermédio da conjunção da tradição e do conhecimento atávico e do poder de transformação das novas gerações, simbolizado pelas cinco tranças de Ynari.

Ao final de sua trajetória, o homem pequenino e Ynari voltam a sentar-se no mesmo lugar onde se encontraram pela primeira vez, em um movimento circular da narrativa: a menina volta ao início, mas transformada pela experiência. Ela pede ao homem pequenino que leve a palavra "guerra" à velha muito velha, para que ela a destrua, completando o ciclo de renovação.

Contudo, antes de Ynari voltar a sua aldeia, o homem lhe diz que é hora de empregar a palavra "despedida", ao que ela responde haver nessa palavra um pouco de "encontro" e de "saudade". Ele pede que explique. A menina diz que tal como o velho muito velho, também inventa palavras, pois quando viu o homem pequenino pela primeira vez, inventou para eles a palavra "amizade". Ele lhe diz, então, que assim como o velho muito velho e a velha muito velha, todos podem inventar e destruir palavras com o coração. Esse pedido pode ser remetido ao papel que se espera de cada angolano, na nova fase de paz vivida pelo país: destruir o que é inútil, permutado por energias renovadas e renovadoras, prenhes de igualdade, como a aldeia do homem pequenino, em que ninguém tem nome e onde não há soba, mas onde todos têm seu papel de destruir e de criar palavras.

A despedida tem sabor de sempre reencontro, uma vez que os amigos combinam de viajar no coração do humbi-humbi, ave que simboliza liberdade. Esta construção simbólica também não gratuita na nova conjunção sociopolítica de Angola, que deseja a liberdade e a paz.

Por fim, seguindo na esteira da oralidade, a história é encerrada com a fórmula "E, como dizem os mais velhos, foi assim que aconteceu" (p. 44), com a qual o narrador retoma a importância da figura do mais velho, como fonte de sabedoria e, por conseguinte, base da sociedade moderna. A oralidade presente na narrativa também é instituída pela repetição de palavras e o emprego de expressões qualificativas com diminutivos, como em "homem muito pequenino" (p. 6), "a avó, que se mexia devagarinho, porque era muito velhinha (e que também estava a ficar pequenina embora não tão pequenininha como o homem que já lhe parecia tão pequenino [...]" (p. 11). A narrativa institui-se como retomada da cultura oral, impregnada da figura do narrador benjaminiano.

\section{Aprendendo a dizer "considerações finais"}

A história de Ynari resgata a tradição oral e a memória atávica do homem, mostrando o poder transformador do verbo, elemento central entre os povos de cultura oral. Além disso, aponta para o papel de cada indivíduo em sua sociedade, já que cada um tem sua magia e deve descobri-la, para colocá-la a serviço de um mundo melhor, como, no caso deste livro, um mundo sem guerras. Conflitos injustificados e que surgem pela incapacidade do homem de perceber suas próprias limitações e pela falta de diálogo, apaziguados pelo poder da palavra. Inscreve-se aí sua universalidade, desvela-se aí sua alegoria a partir do contexto cultural de África. É África e é do Homem - é universal.

Aportando em terras brasílicas, a leitura deste texto oferece nova(s) perspectiva(s), indo ao encontro da proposta de se conhecer a cultura africana, com seus mitos e ritos, perpetuados e perpassados pela linguagem oral, repletos de sabedoria. Esta narrativa, que ensina sem ser pedagogizante, fazendo ressoar o narrador benjaminiano, é enriquecida pela ilustração rica e, por vezes, metafórica, e permite ao leitor a ampliação de seus horizontes de expectativa, envolvendo-o em um universo cultural próprio dos povos africanos, mas que ultrapassa as fronteiras e, como em um espelho, torna visível a própria cultura afrobrasileira, revelando essa veia oral, originária de terras africanas. 
Referências

AGUALUSA, J. E. Barroco tropical. São Paulo: Companhia das Letras, 2009. BAKHTIN, M. Marxismo e filosofia da linguagem. São Paulo: Hucitec, 2006. BENJAMIN, Walter. O narrador. Considerações sobre a obra de Nikolai Leskov.

In: . Magia e técnica, arte e política: ensaios sobre literatura e história da cultura. São Paulo: Brasiliense, 1996.

CÂNDIDO, A. O significado de "Raízes do Brasil". In: HOLANDA, Sérgio Buarque de. Raízes do Brasil. São Paulo: Companhia das Letras, 2010.

CASSIRER, Ernst. Linguagem e mito. São Paulo: Perspectiva, 2006.

CHEVALIER, J.; GHEERBRANT, A. Dicionário de símbolos. Rio de Janeiro: José Olympio, 1998.

DIOUF, Sylviane Anna. As tranças de Bintou. Cosac Naify: São Paulo, 2010.

LARAIA, Roque de Barros. Cultura: um conceito antropológico. Rio de Janeiro: Zahar, 2009. ONDJAKI. Ynari, menina das cinco tranças. São Paulo: Companhia das Letrinhas, 2010. QUEIRÓS, Bartolomeu Campos de. Flora. São Paulo: Global, 2009.

REIS, Carlos. O conhecimento da literatura: introdução aos estudos literários. Porto Alegre: Edipucrs, 2003.

Anexo

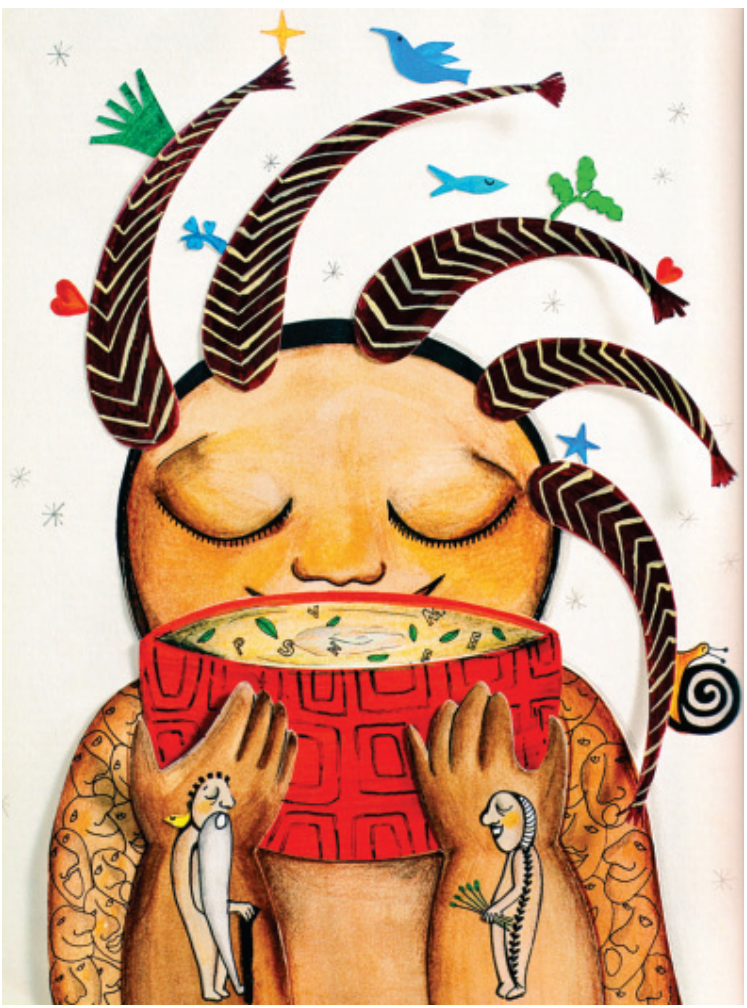

